\title{
Volatile Organic Compounds in Lake Tahoe, Nevada and California, July-September 1997
}

Lake Tahoe, renowned for its high alpine setting and deep, clear waters, is designated an Outstanding Natural Resource Water. It lies in the Lake Tahoe Basin, approximately 240 kilometers $(\mathrm{km})$ from California's San Francisco Bay metropolitan area. Because of its beautiful setting in the mountains of the Sierra Nevada to the west and Carson Range to the east and its proximity to large population centers, the lake has become a mecca for outdoor sports.

U.S. Environmental Protection Agency estimates that nationwide use of personal watercraft (PWC) constituted approximately 4 percent of all watercraft use in 1993 and will rise to over 20 percent by 2007 (U.S. Environmental Protection Agency, 1996). Two-cycle PWC's are estimated to discharge from 20 to 30 percent of the incoming fuel out of the exhaust (National Marine Manufacturers Association, written commun., 1997).

$120^{\circ} 15^{\prime}$

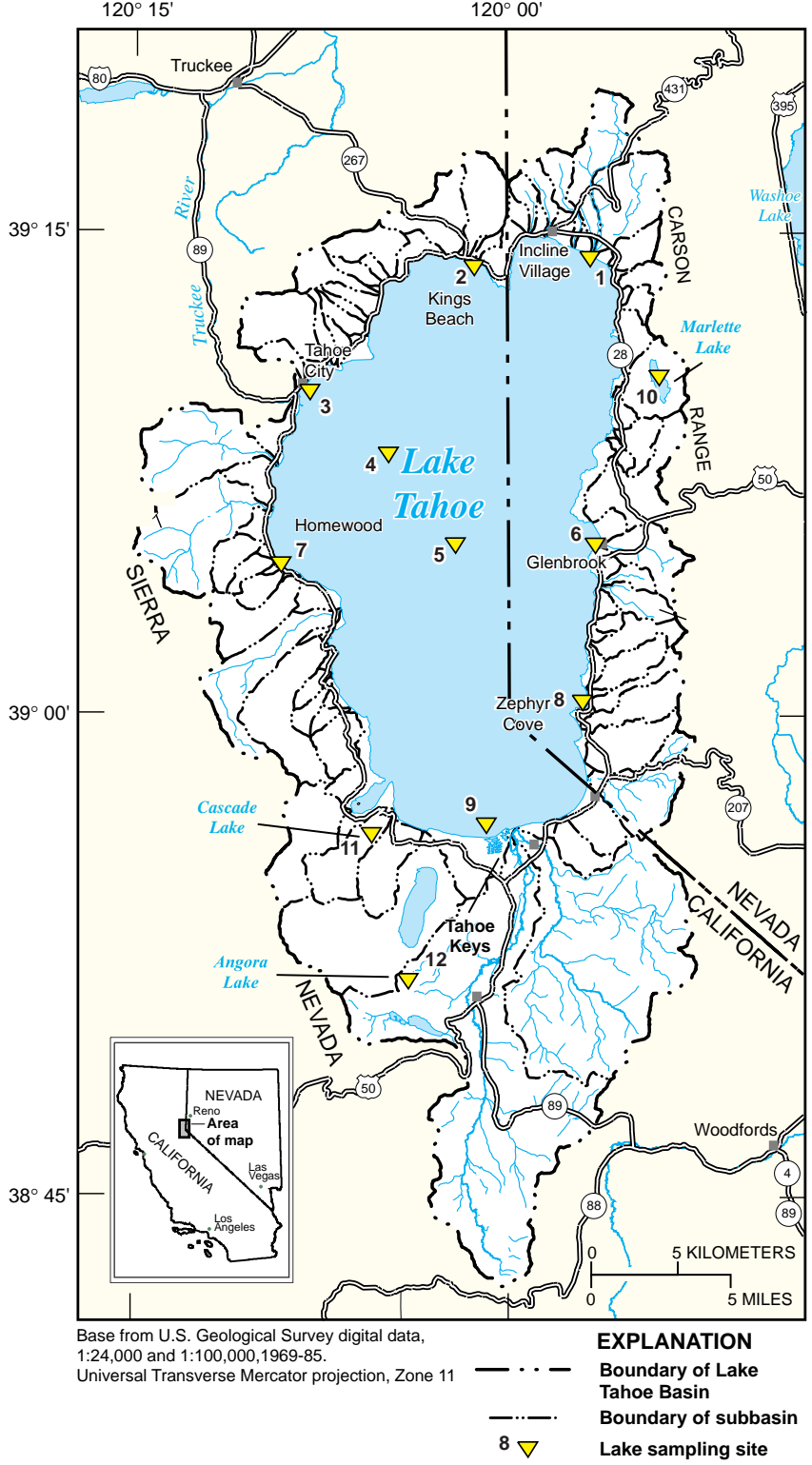

Figure 1. Lake sampling sites in Lake Tahoe Basin, Nevada and California
In February 1997, the Tahoe Regional Planning Agency (TRPA) governing board held hearings to gather information on the potential effects of watercraft powered by carbureted 2-stroke engines on Lake Tahoe water quality and whether their use in the lake should be banned. During the hearings, information about the potential effect of hydrocarbon emissions on lake-water quality was presented. However, no data specific to Lake Tahoe were available to characterize the occurrence of gasoline products from PWC or any other sources or the effects of such products on water quality in Lake Tahoe.

During the summer of 1997, the U.S. Geological Survey (USGS), in cooperation with TRPA and with assistance from Tahoe Research Group (TRG), sampled lake waters within the Lake Tahoe Basin for volatile organic compounds (VOC's) including methyl tert-butyl ether (MTBE), ethyl tert-butyl ether (ETBE), tert-amyl methyl ether (TAME), benzene, toluene, ethylbenzene, and xylene (isomers ortho-, meta-, and para-).

\section{Sampling Sites and Procedures}

Water samples were collected July 29 through August 2 and September 2 through September 5, 1997 (table 1). Site locations are shown in figure 1. During the first sampling period, sites were chosen to be consistent with those where long-term traditional limnological data have been collected by the TRG of the University of California, Davis: nearshore to Tahoe City (site 3) and offshore southeast of Tahoe City (site 4). Site locations during the second sampling period were chosen to provide spatially distributed data where watercraft activity is common. Sampling sites on Lake Tahoe were near Incline Village, Nev. (site 1); Kings Beach, Calif. (site 2); Glenbrook, Nev. (site 6); Homewood, Calif. (site 7); Zephyr Cove, Nev. (site 8); Tahoe Keys, Calif. (site 9); and the deepest part of the lake (site 5). Other lakes sampled during the second sampling period included Marlette Lake, Nev. (site 10); Cascade Lake, Calif. (site 11); and upper Angora Lake, Calif. (site 12). These three lakes were sampled as background reference sites because neither Marlette Lake nor upper Angora Lake has any motorized watercraft traffic. Cascade Lake has limited motorized watercraft traffic consisting of a few boats with small 2-stroke motors that are used by residents of seasonal homes around the lake.

Water temperature, $\mathrm{pH}$, specific conductance, and dissolved-oxygen measurements were made at 1- or 2-meter $(\mathrm{m})$ increments to the deepest sampling point. At the mid-lake Lake Tahoe sites (sites 4 and 5), and at the Marlette Lake, Cascade Lake, and upper Angora Lake sites (sites 10-12), a thermocline was detected and the deepest sampling point was below the thermocline. These onsite measurements were made by using a multiparameter sensor, which was calibrated on location.

Sampling protocols outlined by Shelton (1997) were used for sampling the VOC's. The sampler used was a modified stream sampler lowered to the desired depth on a stainless-steel cable attached to a calibrated reel. The sampling equipment was cleaned before each sample as detailed by Shelton (1997).

Immediately upon retrieval, the sampler was placed in a preservation chamber (Shelton, 1994) to prevent contamination of the samples by atmospheric sources. Quality-control samples consisted of VOC-free water (blanks) exposed to the same sampling equipment and environment as the lake samples (table 1). Samples were preserved with 1:1 hydrochloric acid and sent overnight to the USGS National Water-Quality Laboratory in Arvada, Colo. Presence and concentrations of compounds were determined by gas chromatograph-mass spectrometer (Conner and others, 1998).

\section{Results}

Concentrations of the VOC's are shown in table 1. MTBE was detected in all Lake Tahoe samples. MTBE concentrations at nearshore sites, at a depth of $3 \mathrm{~m}$, ranged from 0.30 microgram per liter $(\mu \mathrm{g} / \mathrm{L})$ near Glenbrook (site 6), to $4.2 \mu \mathrm{g} / \mathrm{L}$ near Tahoe City (site 3 ). The MTBE concentrations at $3-\mathrm{m}$ depth at offshore sites 4 and 5 were $0.59 \mu \mathrm{g} / \mathrm{L}$ and $0.42 \mu \mathrm{g} / \mathrm{L}$, respectively. These results indicate a variability in the spatial distribution of MTBE at shallow depths, with larger concentrations nearer sites with substantial watercraft activity. MTBE concentration near Tahoe City (site 3) on July 29 was $1.5 \mu \mathrm{g} / \mathrm{L}$; on August 2, during a weekend with considerable watercraft activity, the concentration was $4.2 \mu \mathrm{g} / \mathrm{L}$. At the Lake Tahoe 
Table 1. Volatile organic compounds in water samples collected at Lake Tahoe and other nearby alpine lakes, July 29-September 5, 1997

[Concentrations in micrograms per liter unless otherwise denoted; ${ }^{\circ} \mathrm{C}$, degrees Celsius; <, less than; --, not determined]

\begin{tabular}{|c|c|c|c|c|c|c|c|c|c|c|c|c|}
\hline $\begin{array}{c}\text { Site } \\
\text { (fig. 1) }\end{array}$ & $\begin{array}{c}\text { Depth } \\
\text { (meters below } \\
\text { lake surface) }\end{array}$ & Date & $\begin{array}{c}\text { Methyl } \\
\text { tert-butyl } \\
\text { ether }^{1} \\
\text { (MTBE) }\end{array}$ & $\begin{array}{c}\text { Ethyl } \\
\text { tert-butyl } \\
\text { ether } \\
\text { (ETBE) }\end{array}$ & $\begin{array}{l}\text { Tert-amyl } \\
\text { methyl } \\
\text { ether }^{1} \\
\text { (TAME) }\end{array}$ & Benzene $^{1}$ & Toluene $^{1}$ & $\begin{array}{c}\text { Ethyl- } \\
\text { benzene }^{1}\end{array}$ & $\begin{array}{c}\text { Ortho- } \\
\text { xylene }^{1}\end{array}$ & $\begin{array}{c}\text { Meta- and } \\
\text { para- } \\
\text { xylene }^{1}\end{array}$ & $\begin{array}{l}\text { Xylene } \\
\text { (total) }\end{array}$ & $\begin{array}{c}\text { Water } \\
\text { temper- } \\
\text { ature } \\
\left({ }^{\circ} \mathrm{C}\right)\end{array}$ \\
\hline 1 & 3 & Sept. 3 & 0.45 & $<0.054$ & E 0.05 & E 0.5 & 0.13 & E 0.02 & Е 0.03 & Е 0.09 & E 0.1 & -- \\
\hline 2 & 3 & Sept. 3 & 1.7 & $<.054$ & .14 & .13 & .68 & .12 & .20 & .52 & .72 & -- \\
\hline 3 & 3 & July 29 & 1.5 & $<.054$ & E. 09 & .15 & .58 & E. 09 & .16 & .42 & .58 & 18.6 \\
\hline 4 & 3 & Aug. 2 & .59 & $<.054$ & E.04 & $<.06$ & $<.06$ & $<.030$ & $<.064$ & E.03 & E.03 & 17.8 \\
\hline 4 & 10 & Aug. 2 & .61 & $<.054$ & $<.11$ & $<.06$ & $<.07$ & $<.030$ & $<.064$ & E.04 & E.04 & 17.6 \\
\hline 4 & 30 & July 29 & .19 & $<.054$ & E.02 & $<.032$ & $<.04$ & $<.030$ & $<.064$ & $<.064$ & $<.064$ & 8.8 \\
\hline 4 & 30 & Aug. 2 & .26 & $<.054$ & $<.11$ & $<.032$ & $<.04$ & $<.030$ & $<.064$ & $<.064$ & $<.064$ & 8.9 \\
\hline 5 & 3 & Sept. 3 & .42 & $<.054$ & E. 05 & E.04 & E. 09 & $<.030$ & $<.064$ & E.05 & E.05 & 17.8 \\
\hline 5 & 30 & Sept. 3 & .18 & $<.054$ & $<.11$ & E.02 & E.04 & $<.030$ & $<.064$ & $<.064$ & $<.064$ & 11.5 \\
\hline \multicolumn{13}{|c|}{ Other Nearby Lake Samples (background sites) } \\
\hline 10 & 3 & Sept. 5 & $<.11$ & $<.054$ & $<.11$ & $<.032$ & $<.04$ & $<.030$ & $<.064$ & $<.064$ & $<.064$ & 17.0 \\
\hline 10 & 9.1 & Sept. 5 & $<.11$ & $<.054$ & $<.11$ & $<.032$ & E.01 & $<.030$ & $<.064$ & $<.064$ & $<.064$ & 15.0 \\
\hline 11 & 3 & Sept. 4 & $<.11$ & $<.054$ & $<.11$ & $<.032$ & E. 04 & $<.030$ & $<.064$ & E.02 & E.02 & 18.3 \\
\hline 11 & 15 & Sept. 4 & $<.11$ & $<.054$ & $<.11$ & $<.032$ & E.02 & $<.030$ & $<.064$ & $<.064$ & $<.064$ & 6.9 \\
\hline 12 & 3 & Sept. 4 & $<.11$ & $<.054$ & $<.11$ & $<.032$ & E. 02 & $<.030$ & $<.064$ & $<.064$ & $<.064$ & 16.8 \\
\hline 12 & 10 & Sept. 4 & $<.11$ & $<.054$ & $<.11$ & $<.032$ & $<.04$ & $<.030$ & $<.064$ & $<.064$ & $<.064$ & 7.8 \\
\hline \multicolumn{13}{|c|}{ Quality-Control Samples } \\
\hline & Sampler blank & July 28 & $<.11$ & $<.054$ & $<.11$ & $<.032$ & $<.04$ & $<.030$ & $<.064$ & $<.064$ & $<.064$ & -- \\
\hline & Ambient blank & July 29 & Е.07 & $<.054$ & $<.11$ & $<.032$ & $<.04$ & $<.030$ & $<.064$ & $<.064$ & $<.064$ & -- \\
\hline
\end{tabular}

${ }^{1}$ When an "E" is reported, the compound has passed all criteria used to identify its presence, and only the concentration is estimated (Conner and others, 1998). When a "<" is reported, compound was not detected in that sample.

offshore site (site 4 ) at a depth of $30 \mathrm{~m}$, the MTBE concentration was 0.19 $\mu \mathrm{g} / \mathrm{L}$ on July 29; four days later, on August 2, the MTBE concentration was $0.26 \mu \mathrm{g} / \mathrm{L}$.

ETBE was not found at any site. TAME was detected in samples from all nearshore sites, with concentrations up to $0.20 \mu \mathrm{g} / \mathrm{L}$ near Tahoe City (site 3) on September 2. TAME concentration at the offshore site (site 4) at 30-m depth on July 29 was estimated to be $0.02 \mu \mathrm{g} / \mathrm{L}$ and at the offshore site (site 5) at 3-m depth on September 3 was estimated to be $0.05 \mu \mathrm{g} / \mathrm{L}$ (see footnote, table 1 )

Benzene was detected in all nearshore samples from a depth of $3 \mathrm{~m}$ in concentrations ranging from an estimated $0.04 \mu \mathrm{g} / \mathrm{L}$ near Glenbrook (site 6) on September 2, to an estimated $0.5 \mu \mathrm{g} / \mathrm{L}$ near Incline Village (site 1 ) on September 3. Benzene concentrations from near Tahoe City (site 3), increased from $0.15 \mu \mathrm{g} / \mathrm{L}$ on July 29 to $0.33 \mu \mathrm{g} / \mathrm{L}$ on August 2 (weekend with heavy watercraft activity). Benzene also was detected at the offshore site (site 5) at estimated concentrations of $0.04 \mu \mathrm{g} / \mathrm{L}$ at $3 \mathrm{~m}$ depth and of $0.02 \mu \mathrm{g} / \mathrm{L}$ at $30 \mathrm{~m}$ on September 3 .

Toluene was detected at all nearshore sites at $3 \mathrm{~m}$ in concentrations ranging from an estimated $0.1 \mu \mathrm{g} / \mathrm{L}$ near Glenbrook (site 6) on September 2, to $0.70 \mu \mathrm{g} / \mathrm{L}$ near Zephyr Cove (site 8) on that same date. On July 29, near Tahoe City (site 3), the toluene concentration was $0.58 \mu \mathrm{g} / \mathrm{L}$ and had increased to $1.9 \mu \mathrm{g} / \mathrm{L}$ on August 2. On September 3, at the offshore site (site 5), the estimated toluene concentration at $3 \mathrm{~m}$ was $0.09 \mu \mathrm{g} / \mathrm{L}$ and at $30 \mathrm{~m}$ was $0.04 \mu \mathrm{g} / \mathrm{L}$.

Ethylbenzene was detected in all samples from shallow $(3 \mathrm{~m})$ nearshore sites. The highest concentration of ethylbenzene, $0.39 \mu \mathrm{g} / \mathrm{L}$, was detected at the Tahoe City shallow site (site 3) on August 2. Ethylbenzene was not detected in any offshore samples. Total xylene was detected at all nearshore sites in concentrations ranging from an estimated $0.06 \mu \mathrm{g} / \mathrm{L}$ near Glenbrook (site 6) on September 2, to $2.2 \mu \mathrm{g} / \mathrm{L}$ near Tahoe City (site 3) on August 2. On September 3, an estimated meta- and paraxylene concentration of $0.05 \mu \mathrm{g} / \mathrm{L}$ was detected at an offshore site (site 5) at $3 \mathrm{~m}$. The concentration of xylene for all other offshore samples (sites 4 and 5) was less than the detection limit of $0.064 \mu \mathrm{g} / \mathrm{L}$.

With exceptions discussed below, no benzene, toluene, ethylbenzene, xylene, MTBE, ETBE, or TAME were detected in Marlette Lake (site 10), Cascade Lake (site 11), or upper Angora Lake (site 12). Toluene was detected in estimated concentrations ranging from 0.01 to $0.04 \mu \mathrm{g} / \mathrm{L}$; however, three of six quality-control samples also had estimated concentrations ranging from 0.01 to $0.04 \mu \mathrm{g} / \mathrm{L}$. Total xylene in Cascade Lake (site 11) at a depth of $3 \mathrm{~m}$ on September 4 was measured at an

estimated $0.02 \mu \mathrm{g} / \mathrm{L}$, but a quality-control sample also had an estimated concentration of $0.02 \mu \mathrm{g} / \mathrm{L}$. Because of these quality-control results, the toluene and xylene detections in the other alpine lakes may be from inadvertent sample contamination and may not be representative of conditions at those sites.

\section{Summary and Conclusions}

MTBE was detected in all samples from Lake Tahoe in concentrations ranging from 0.18 to $4.2 \mu \mathrm{g} / \mathrm{L}$ and to depths of $30 \mathrm{~m}$. ETBE was not detected in any samples. Concentrations of TAME, benzene, toluene, ethylbenzene, and xylene ranged from non-detection to $2.2 \mu \mathrm{g} / \mathrm{L}$ (xylene; site 3 ). Concentrations of all compounds varied spatially and temporally during the sampling period. No exceedances of known drinking water standards or health advisories were detected.

\section{-Carol J. Boughton and Michael S. Lico}

\section{References Cited}

Conner, B.F., Rose, D.L., Noriega, M.C., Murtagh, L.K., and Abney, S.R., 1998, Methods of analysis by the USGS-NWQL-Determination of 86 volatile organic compounds in water by gas chromatography/mass spectrometry, including detections less than reporting limit: U.S. Geological Survey Open-File Report 97-829, 76 p.

Shelton, L.R., 1994, Field guide for collecting and processing streamwater samples for the National Water-Quality Assessment Program: U.S. Geological Survey Open-File Report 94-455, 42 p.

1997, Field guide for collecting samples for analysis of volatile organic compounds in stream water for the National Water-Quality Program: U.S. Geological Survey Open-File Report 97-401, 14 p.

U.S. Environmental Protection Agency, 1996, Regulatory impact analysis-Control of air pollution emission standards for new nonroad spark-ignition marine engines: Office of Air and Radiation Publication ANR-443, unpaginated.

\section{For more information on water resources in Nevada, contact:}

Public Information Assistant

U.S. Geological Survey

333 W. Nye Lane

Carson City, NV 89706 tel.: (702) 887-7649

fax: (702) 887-7629

email: usgsinfo_nv@usgs.gov

URL: http://wwwnv.wr.usgs.gov 